\title{
Pengaruh kompetensi auditor independen dan tekanan anggaran waktu terhadap pendeteksian fraud
}

\author{
Presti Rosiana \\ Akuntansi, Fakultas Bisnis Institut Teknologi dan Bisnis Kalbis \\ Indra Mahardika Putra* \\ Akuntansi, Fakultas Bisnis Institut Teknologi dan Bisnis Kalbis

\section{Yopie Aprianto Setiawan} \\ Akuntansi, Fakultas Bisnis Institut Teknologi dan Bisnis Kalbis
}

Paper type Research paper
Keywords: $\quad$ fraud detection, competence, auditors, time budget pressures method. Statistical testing uses multiple linear regression analysis with a significance level of $5 \%$. The type of research used is quantitative by using a population of auditors working at the Public Accounting Firm (KAP) in DKI Jakarta. Data is obtained by distributing questionnaires to auditors who meet the criteria. The results of this study, it can be concluded that Auditor Competency has an effect on Fraud Detection, but Time Budget Pressure has no effect on Fraud Detection.

\begin{abstract}
Abstrak
Penelitian ini bertujuan untuk menguji pengaruh kompetensi auditor independen dan tekanan anggaran waktu terhadap pendeteksian fraud. Populasi dari penelitian ini yaitu para auditor di wilayah Jakarta. Pengumpulan data dalam penelitian ini menggunakan metode survey. Pengujian statistik menggunakan analisis regresi linear berganda dengan tingkat signifikansi 5\%. Jenis penelitian yang digunakan adalah kuantitatif dengan menggunakan populasi Auditor yang bekerja pada Kantor Akuntan Publik (KAP) di DKI Jakarta. Data diperoleh dengan menyebarkan kuesioner kepada Auditor yang memenuhi kriteria. Hasil dari penelitian ini, dapat disimpulkan bahwa Kompetensi Auditor berpengaruh dalam Pendeteksian Fraud, namun Tekanan Anggaran Waktu tidak memiliki pengaruh terhadap Pendeteksian Fraud.
\end{abstract}

*Email korespondensi: indra.putra@kalbis.ac.id

Pedoman Sitasi: Rosiana, P., Putra, I.M., \& Setiawan, Y.A (2019). Pengaruh kompetensi auditor independen dan tekanan anggaran waktu terhadap pendeteksian fraud. Jurnal Manajemen Strategi dan Aplikasi Bisnis, 2(1), 45 - 52
Received: 27 Dec 2018

Accepted: 5 Feb 2019

Online: 15 Feb 2019

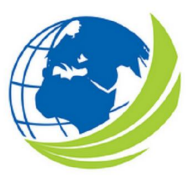

\author{
Jurnal Manajemen \\ Strategi dan Aplikasi \\ Bisnis, Vol 2, No.1, April \\ 2019, \\ pp. 45 - 52 \\ eISSN 2655-237X
}




\section{PENDAHULUAN}

Kompetensi auditor memiliki peranan penting untuk pendeteksian fraud. Kompetensi diperoleh dari berbagai kegiatan peningkatan pengetahuan dan ketrampilan seperti pendidikan, pelatihan, dan pengalaman. Yusrianti (2015) menjelaskan bahwa pengetahuan (knowledge) dan pengalaman merupakan komponen penting dalam tugas audit. Pengalaman membantu auditor untuk menyelesaikan penugasan audit dan mengidentfikasi temuan-temuan yang diperoleh. Pengetahuan auditor terkait industri bisnis klien, perencanaan audit, penyusunan program audit yang efektif, dan analisis kondisi yang berpotensi munculnya fraud (Red Flag) mendukung auditor untuk mendeteksi fraud yang terjadi. Kesimpulannya, kompetensi auditor akan meningkatkan kepekaan auditor dalam pendeteksian fraud.

Mengingat bahwa setiap perikatan audit memiliki jangka waktu penugasan (anggaran waktu) yang telah disepakati antara kantor akuntan publik (KAP) dengan klien, auditor seringkali terkendala dengan sempitnya anggaran waktu untuk proses audit. Ketidakseimbangan antara tugas audit dengan anggaran waktu seringkali memunculkan tekanan anggaran waktu atas auditor. Tekanan anggaran waktu merupakan kondisi ketika auditor memperoleh tekanan untuk dapat menyelesaikan penugasan auditnya sesuai dengan waktu yang telah disepakati atau ditetapkan. Permasalahannya adalah ketika objek audit cukup kompleks dan durasi audit (waktu) dianggarkan tidak sesuai dengan kondisi tersebut. Dengan demikian, auditor hanya melakukan prosedur audit pada pos-pos tertentu untuk mengejar waktu yang dianggarkan sehingga kemungkinan pendeteksian fraud oleh auditor akan semakin kecil. Kesimpulannya, tekanan anggaran waktu dimungkinkan mengurangi kepekaan auditor dalam pendeteksian fraud.

Penelitian ini merupakan pengembangan dari penelitian terdahulu yang dilakukan oleh Widiyastuti dan Pamudji (2009), Anggriawan (2014), Srikandi (2015), dan Simanjuntak (2015). Objek dari penelitian ini adalah auditor independen yang bekerja di kantor akuntan publik di daerah Jakarta. Penelitian terdahulu, objek penelitian yang digunakan pada penelitian merupakan auditor pemerintah di Jakarta dan Sumatera Utara (Widiyastuti dan Pamudji, (2009) dan Simanjuntak, 2015), sedangkan objek penelitian yang digunakan oleh Anggriawan (2014) dan Srikandi (2015) adalah auditor independen yang bekerja di kantor akuntan publik (KAP) wilayah DIY dan Bandung. Penelitian dengan objek berbeda akan meningkatkan robustness hasil penelitian. Pengembangan berikutnya adalah penambahan variabel tekanan anggaran waktu sebagai variabel independen.

Pendeteksian fraud dalam penelitian ini didefinisikan sebagai kemampuan seorang auditor dalam mendeteksi fraud. Kompetensi dalam penelitian ini adalah kompetensi yang diperoleh dari pendidikan formal, sertifikasi, pengetahuan, dan pengalaman auditor. Adapun tekanan anggaran waktu merupakan kondisi yang ditimbulkan dari adanya keterbatasan waktu dalam penugasan audit. Asumsi di penelitian ini adalah pendeteksian fraud dipengaruhi oleh kompetensi dan tekanan anggaran waktu. Berdasarkan latar belakang masalah, definisi, dan asumsi di atas, rumusan masalah penelitian sebagai berikut: (1) pengaruh kompetensi auditor terhadap pendeteksian fraud; (2) pengaruh tekanan anggaran waktu terhadap pendeteksian fraud. Lingkup yang menjadi batasan penelitian di riset ini sebagai berikut: (1) responden dalam penelitian adalah para auditor yang bekerja di KAP wilayah Jakarta; (2) penelitian ini fokus pada tiga topik utama yaitu kompetensi auditor, pendeteksian fraud, dan tekanan anggaran waktu.

\section{KAJIAN PUSTAKA}

Teori Agens.

Ketidaksimetrisan informasi merupakan kondisi dimana manajer memiliki informasi lebih baik mengenai kebenaran laporan posisi dan hasil dari kegiatan operasi dibandingkan dengan pemilik perusahaan (Messier et al., 2012:6). Manajer seringkali berkepentingan untuk melaporkan pengelolaan bisnis perusahaan yang memberikan manfaat lebih banyak kepada manajer. Sedangkan pemilik, laporan keuangan disajikan secara relevan dan handal (Castellani, 2008). Jasa audit muncul 
Jurnal Manajemen Strategi dan Aplikasi Bisnis, 2(1), 45-52

Presti Rosiana et al. Pengaruh kompetensi auditor...

karena kebutuhan terhadap akuntabilitas pengelolaan bisnis (Messier et al. 2012, p.5).

Pengertian Auditor Independen.

Elfarini (2007) menyebutkan, untuk mengurangi atau meminimalkan kecurangan yang dilakukan oleh manajemen dan membuat laporan keuangan yang dibuat manajemen lebih dapat dipercaya (reliable) maka diperlukan pengujian dan dalam hal itu pengujian tersebut hanya dapat dilakukan oleh pihak ketiga yang independen yaitu auditor independen. Dengan demikian, dapat disimpulkan bahwa auditor independen adalah seseorang yang disebut sebagai pihak independen yang telah memperoleh izin untuk memberikan jasa audit, reviu, dan jasa asurans lainnya untuk mengurangi atau meminimalkan kecurangan yang dilakukan oleh manajemen dengan membuat laporan keuangan yang dibuat manajemen lebih dapat dipercaya (reliable).

Pengertian Kompetensi.

Pengetahuan auditor mencakup pengetahuan mengenai industri bisnis klien, bagaimana melakukan perencanaan audit, menyusun program audit yang efektif dan menganalisis kondisi yang berpotensi munculnya fraud (Red Flag). Seluruh indikator tersebut harus dimiliki oleh auditor mengingat bahwa audit merupakan pekerjaan yang berisiko tinggi dan apabila auditor tidak memiliki kompetensi terhadap hal-hal tersebut maka akan berdampak tidak hanya pada auditor itu sendiri, tapi juga berdampak pada reputasi profesi dan reputasi kantor akuntan publik yang menaunginya.

Pengertian Fraud.

Fraud merupakan tindakan kecurangan yang disengaja. Seperti yang disebutkan pada Statement on Auditing Standards (SAS) No. 1, auditor independen bertanggung jawab atas penemuan salah saji material baik yang disebabkan oleh error atau fraud. Faktor utama yang membedakan fraud dan error adalah tindakan yang mendasarinya, apakah tindakan tersebut dilakukan secara disengaja atau tidak. Jika tindakan tersebut dilakukan secara sengaja, maka disebut kecurangan (fraud) dan jika tindakan tersebut dilakukan secara tidak sengaja, maka disebut dengan kekeliruan (error) (Widiyastuti dan Pamudji, 2009).

Pengertian Tekanan Anggaran Waktu.

Fraud merupakan tindakan kecurangan yang disengaja. Seperti yang disebutkan pada Statement on Auditing Standards (SAS) No. 1, auditor independen bertanggung jawab atas penemuan salah saji material baik yang disebabkan oleh error atau fraud. Faktor utama yang membedakan fraud dan error adalah tindakan yang mendasarinya, apakah tindakan tersebut dilakukan secara disengaja atau tidak. Jika tindakan tersebut dilakukan secara sengaja, maka disebut kecurangan (fraud) dan jika tindakan tersebut dilakukan secara tidak sengaja, maka disebut dengan kekeliruan (error) (Widiyastuti dan Pamudji, 2009). Tekanan anggaran waktu (time budget pressure) adalah kondisi ketika auditor memperoleh tekanan untuk dapat menyelesaikan penugasan auditnya sesuai dengan anggaran waktu yang telah disepakati / ditetapkan. Sedangkan batas waktu (time deadline) berhubungan dengan tekanan untuk menyelesaikan pekerjaan audit dengan tanggal tertentu (Maulina, Anggraini, \& Anwar, 2010). Kedua tekanan waktu inilah yang pada akhirnya akan mempengaruhi kinerja auditor dalam mendeteksi fraud. Kerangka konseptual dalam penelitian ini adalah : 


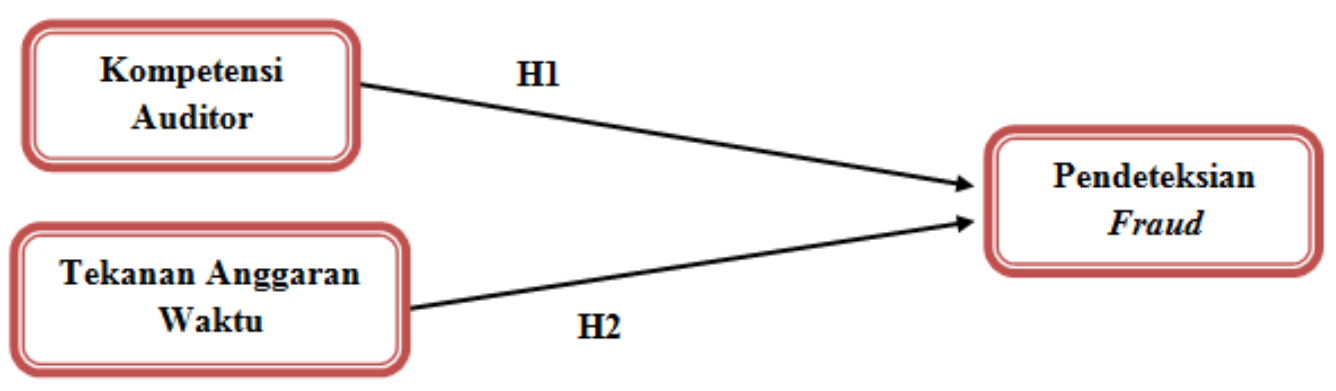

\section{Gambar 1. Kerangka Konseptual}

Hipotesis penelitian:

H1: Kompetensi auditor berpengaruh positif terhadap pendeteksian fraud.

H2: Tekangan anggaran waktu berpengaruh negatif terhadap pendeteksian fraud.

\section{METODE PENELITIAN}

Strategi penelitian

Penelitian kuantitatif dipilih di dalam penelitian ini karena sampel yang digunakan adalah sampel dari populasi auditor yang bekerja di KAP yang terdaftar di BPK RI dengan menggunakan instrumen penelitian dalam bentuk kuesioner yang kemudian akan dianalisis secara statistik untuk menguji hipotesis yang telah ditetapkan.

Jenis data yang digunakan adalah jenis data kuantitatif, yaitu data yang berbentuk angka atau data kualitatif yang diangkakan atau scoring (Sugiyono, 2016: 6). Penelitian ini menggunakan data ordinal yang diperoleh melalui skala Likert pada kuesioner. Penelitian ini menggunakan data eksternal dengan jenis primer karena data dalam penelitian ini diolah sendiri, dan data tersebut merupakan data yang diperoleh langsung dari auditor sebagai objek penelitian melalui kuesioner. Selain itu, penelitian ini juga menggunakan data eksternal dengan jenis sekunder karena perolehan data auditor dan kantor akuntan publik yang terdaftar di BPK RI untuk daerah Jakarta didapatkan melalui situs resmi (www.sikap.go.id).

Penelitian ini mengumpulkan data yang jelas, akurat, dan relevan yang berkaitan dengan topik penelitian melalui dua cara, yaitu:

1. Penelitian Kepustakaan (Library Search).

Penelitian kepustakaan merupakan pengumpulan data yang diperoleh dengan membaca dan mempelajari literatur-literatur seperti buku ilmiah, jurnal atau artikel ilmiah, pernyataan standar audit, undang-undang akuntan publik, dan sumber-sumber lainnya yang berkaitan dengan topik penelitian.

2. Angket (Questionnaire).

Angket merupakan teknik pengumpulan data dengan cara membuat daftar pertanyaan atau pernyataan untuk diisi oleh responden. Penelitian ini menggunakan pertanyaan tertutup, yaitu pertanyaan yang telah disediakan jawabannya sehingga responden hanya perlu memilih opsi yang sesuai dengan pandangannya saja. Alasan mengapa penelitian ini menggunakan pertanyaan tertutup adalah karena jawaban dari pertanyaan tertutup tidak bervariasi sehingga lebih mudah untuk diolah.

Sampel penelitian

Objek penelitian yang dipilih adalah kompetensi auditor, tekanan anggaran waktu, dan pendeteksian fraud. Populasi yang dipilih dalam penelitian ini adalah seluruh auditor independen yang bekerja di kantor akuntan publik daerah Jakarta yang terdaftar di BPK-RI sejumlah 482 orang. Jumlah sampel 
Jurnal Manajemen Strategi dan Aplikasi Bisnis, 2(1), 45-52

Presti Rosiana et al. Pengaruh kompetensi auditor...

yang akan diambil untuk penelitian ini berdasarkan pada poin ke-3 (tiga) yang dikemukakan Roscoe dalam Sugiyono (2014: 129-130). Perhitungannya adalah sebagai berikut :

Variabel Independen (X1) : : Kompetensi Auditor

Variabel Independen (X2) : : Tekanan Anggaran Waktu

Variabel Dependen $(\mathrm{Y}) \quad$ : Pendeteksian Fraud

Jumlah Variabel $\quad: 4$ (Empat)

Jumlah Anggota sampel $\quad: 10 \times 3=30$ (minimal)

Berdasarkan perhitungan di atas, maka diperoleh jumlah sampel yang peneliti harus ambil minimal sebanyak 30 orang auditor.

Teknik analisis

Untuk menganalisis dan menguji hipotesis, peneliti menggunakan metode analisis deskriptif dan regresi linier berganda dengan bantuan program Microsoft Excel 2007. Setelah semua data yang dibutuhkan dalam penelitian ini terkumpul, kemudian dilakukan analisis deskriptif untuk memberikan gambaran mengenai masalah yang diteliti.

\section{HASIL DAN PEMBAHASAN}

Analisis Regresi Berganda

Setelah melakukan uji asumsi klasik (uji normalitas, uji multikolinearitas, dan uji heterokedastisitas) sehingga data tersebut layak dan memenuhi syarat untuk melakukan pengujian hipotesis pada model penelitian ini. Tujuan dari analisis regresi berganda yaitu untuk mengetahui pengaruh variabel bebas yaitu kompetensi auditor dan tekanan waktu anggaran terhadap variable terikat yaitu pendeteksian fraud.

Korelasi antara kompetensi auditor dan tekanan waktu anggaran dengan pendeteksian fraud adalah sebesar 0.743, dengan koefisien determinasi 0.525 (adjusted R Square). Dengan demikian dapat dinyatakan bahwa variasi pendeteksian fraud mampu dijelaskan oleh kompetensi auditor dan tekanan waktu anggaran sebesar 52.50\%, dan sisanya dipengaruhi faktor lain di luar model.

\section{Tabel 1. Output Analisis Regresi Linier Berganda}

\begin{tabular}{|c|c|c|c|c|c|}
\hline \multirow{2}{*}{ Model } & \multicolumn{2}{|c|}{$\begin{array}{l}\text { Undstandardized } \\
\text { Coeffecients }\end{array}$} & \multirow{2}{*}{$\begin{array}{c}\begin{array}{c}\text { Standardized } \\
\text { Coefficients }\end{array} \\
\text { Beta } \\
\end{array}$} & \multirow[b]{2}{*}{$\mathrm{t}$} & \multirow[b]{2}{*}{ Sig. } \\
\hline & $\mathrm{B}$ & Std. Error & & & \\
\hline Konstant & 2.352 & 1.278 & & 0.34 & 0.735 \\
\hline $\mathrm{X} 1$ & 0.297 & 0.067 & 0.421 & 4.397 & 0.000 \\
\hline $\mathrm{X} 2$ & -0.144 & 0.074 & 0.177 & 1.939 & 0.055 \\
\hline
\end{tabular}

Sumber: SPSS Versi 22

Berdasarkan hasil Tabel 1 diatas, maka model penelitian yang diajukan dalam persamaan regresi linier berganda adalah sebagai berikut:

$\mathrm{Y}=2.352+0,297$ kompetensi auditor - 0,144 tekanan waktu $+\mathrm{e}$ 


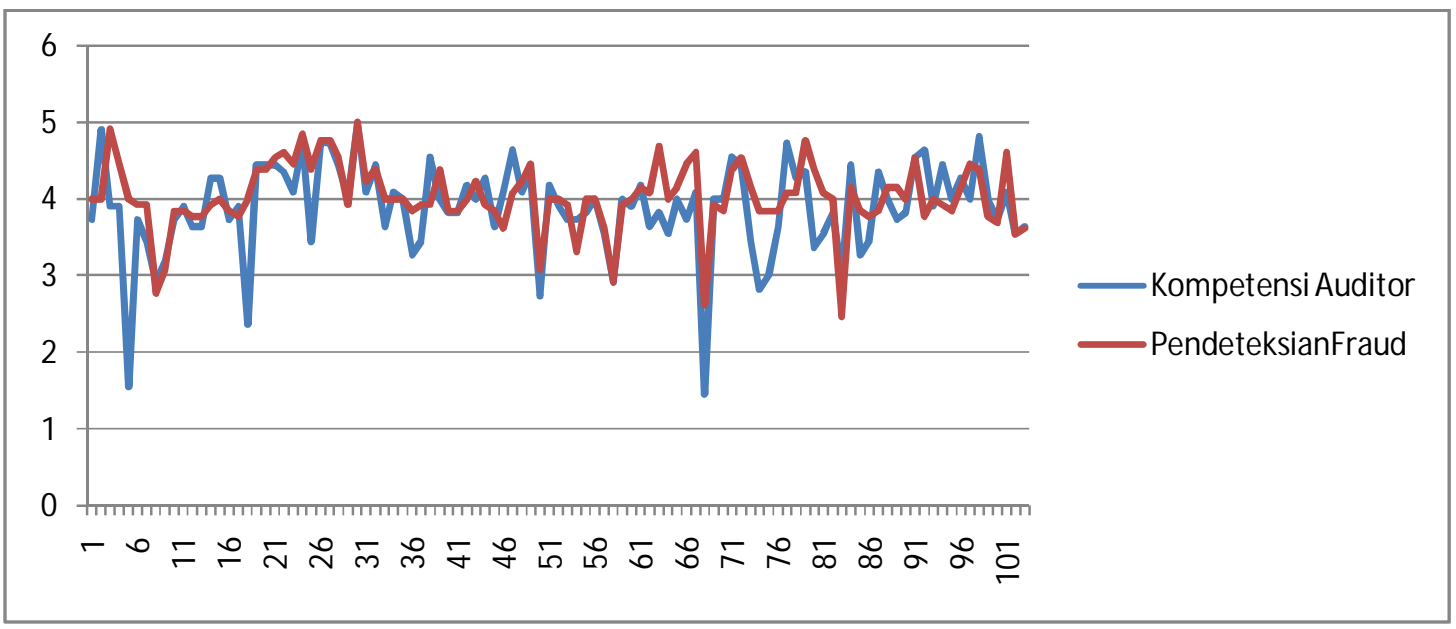

Gambar 2. Kompetensi Auditor dan Pendeteksian Fraud

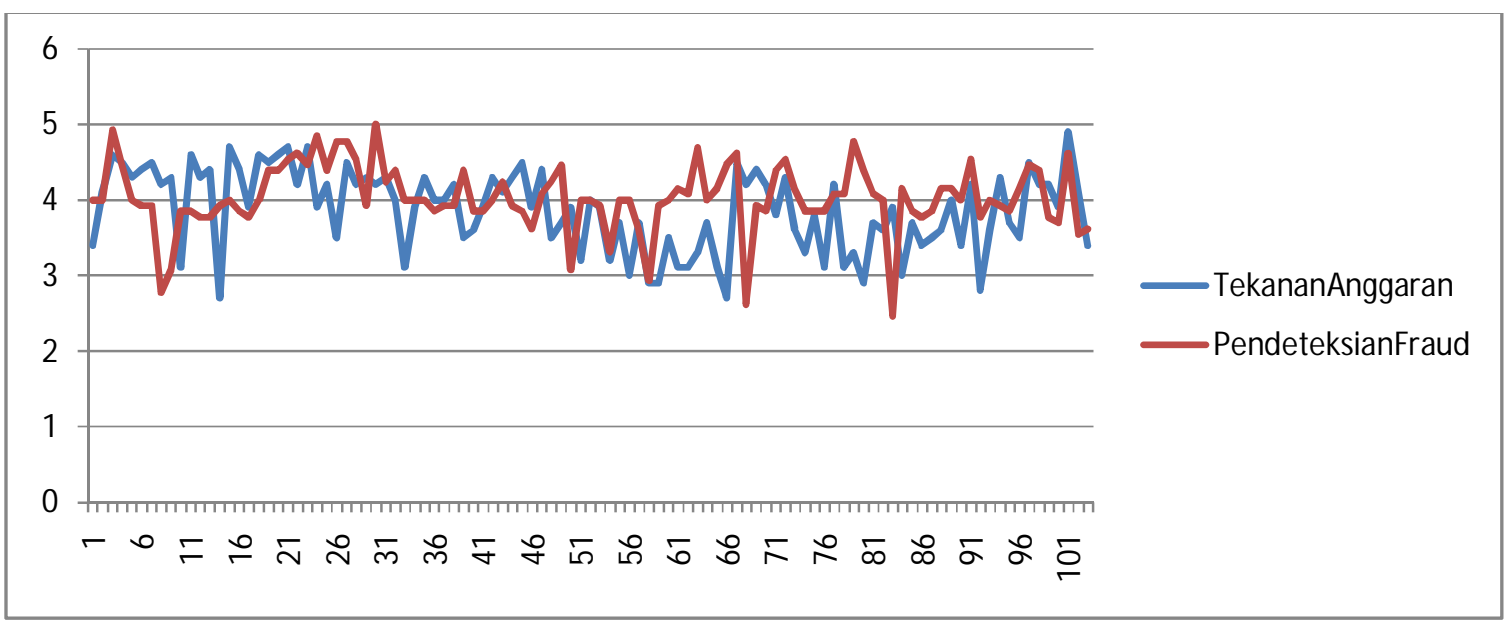

\section{Gambar 3. Tekanan Anggaran Waktu dan Pendeteksian Fraud}

\section{KESIMPULAN}

Berdasarkan hasil analisis data dan pembahasan yang sudah dilakukan, maka dapat disimpulkan bahwa: pertama, variabel Kompetensi Auditor memiliki pengaruh terhadap variabel Pendeteksian Fraud. Hal ini ditunjukkan dengan nilai signifikan kompetensi auditor terhadap pendeteksian fraud sebesar 0,000 sehingga signifikan dibawah dari 0,05. Kedua, variabel Tekanan Anggaran Waktu tidak memiliki pengaruh terhadap pendeteksian fraud. Hal ini ditunjukkan dengan nilai signifikan tekanan anggaran waktu terhadap pendeteksian fraud sebesar 0,055 sehingga signifikan dibawah dari 0,05.

\section{Keterbatasan.}

Penelitian ini tidaklah sempurna dikarenakan masih memiliki beberapa keterbatasan yang akhirnya menyebabkan ketidaksempurnaan dalam penelitian ini. Berikut ini adalah beberapa keterbatasan yang ditemui oleh Peneliti dalam melakukan penelitian ini:

1. Penelitian ini menggunakan metode pengumpulan data melalui kuesioner yang dititipkan atau ditinggal di Kantor Akuntan Publik (KAP) hingga sampai waktu yang telah disepakati. Hal ini menyebabkan data yang diperoleh oleh Peneliti hanya berdasarkan persepsi responden saja sehingga Peneliti tidak dapat mengawasi kebenaran dari jawaban atas pertanyaan yang ada di dalam kuesioner tersebut. 
Jurnal Manajemen Strategi dan Aplikasi Bisnis, 2(1), 45-52

Presti Rosiana et al. Pengaruh kompetensi auditor...

2. Kantor Akuntan Publik (KAP) yang menjadi tempat pengambilan data oleh Peneliti memiliki kesibukan yang berbeda-beda. Sehingga tidak sedikit dari Kantor Akuntan Publik (KAP) yang dihubungi oleh Peneliti menolak untuk mengisi kuesioner tersebut. Sehingga Peneliti hanya memperoleh 5 Kantor Akuntan Publik (KAP) yang bersedia untuk mengisi Kuesioner tersebut.

Berdasarkan keterbatasan-keterbatasan yang ditemui oleh Peneliti dalam melakukan penelitian ini, Peneliti mencoba memberikan saran yang mungkin akan berguna bagi para Peneliti lain yang ingin melakukan penelitian lanjutan. Berikut beberapa sarannya:

1. Populasi dan sampel dalam penelitian ini harus diperluas agar hasil penelitiannya dapat mencerminkan kenyataan yang sesungguhnya.

2. Penelitian selanjutnya dapat dilengkapi dengan melakukan observasi yang lebih mendalam tidak hanya menggunakan kuesioner saja.

\section{REFERENSI}

Chung, N., Song, H. G., \& Lee, H. (2017). Consumers' impulsive buying behavior of restaurant products in social commerce. International Journal of Contemporary Hospitality Management, 29(2), 709731.

American Institute of Certified Public Accountants Auditing Standards (SAS) No. 99, "Consideration of Fraud in a Financial Statement Audit".

Anggriawan, E. F. (2014). Pengaruh Pengalaman Kerja, Skeptisme Profesional, dan Tekanan Waktu Terhadap Kemampuan Auditor Dalam Mendeteksi Fraud (Studi Empiris Pada Kantor Akuntan Publik di DIY). Jurnal Nominal Volume III, No. 2.

Elfarini, E. C. (2007). Pengaruh Kompetensi dan Independensi Auditor terhadap Kualitas Audit (Studi Empiris pada Kantor Akuntan Publik di Jawa Tengah). Skripsi Sarjana Akuntansi Universitas Negeri Semarang.

Ghozali, I. (2016). Aplikasi Analisis Multivariate Dengan Program IBM SPSS 23. Semarang: Badan Penerbit Universitas Diponegoro.

Hartan, T. H. (2016). Pengaruh Skeptisme Profesional, Independensi dan Kompetensi Terhadap Kemampuan Auditor Mendeteksi Kecurangan (Studi Empiris Pada Inspektorat Daerah Istimewa Yogyakarta). Jurnal Profita, Edisi 3.

Hilmi, F. (2011). "Pengaruh Pengalaman, Pelatihan, dan Skeptisisme Profesional Auditor Terhadap Pendeteksian Kecurangan (Studi Empiris Pada Kantor Akuntan Publik di Wilayah Jakarta)". Skripsi Sarjana Akuntansi Universitas Islam Negeri Syarif Hidayatullah Jakarta.

Inapty, B. A. (2007). "Pengaruh Konflik Biaya Dengan Kualitas Audit Terhadap Dysfunctional Behaviour (Studi Empiris Pada Kantor Akuntan Publik di Indonesia)". Tesis Pascasarjana Magister Sains Akuntansi Universitas Diponegoro, Semarang.

International Standard on Auditing 240, "The Auditor's Responsibilities Relating To Fraud in an Audit of Financial Statements".

Maulina, M., Anggraini, R., \& Anwar, C. (2010). Pengaruh Tekanan Waktu dan Tindakan Supervisi Terhadap Penghentian Prematur atas Prosedur Audit. Simposium Nasional Akuntansi XIII Purwokerto.

Rahayu, S. K., \& Suhayati, E. (2010). Auditing: Konsep Dasar dan Pedoman Pemeriksaan. Yogyakarta: Graha Ilmu.

Rustiarini, N. W., \& Novitasari, N. L. (2014). Persepsi Auditor Atas Tingkat Efektivitas Red Flags Untuk Mendeteksi Kecurangan. Jurnal Akuntansi Multiparadigma Volume 5,

Silalahi, S. P. (2013). Pengaruh Etika, Kompetensi, Pengalaman Audit dan Situasi Audit Terhadap Skeptisme Profesional Auditor. Jurnal Ekonomi, Volume 21, Nomor 3.

Simanjuntak, S. N. (2015). Pengaruh Independensi, Kompetensi, Skeptisme Profesional dan Profesionalisme Terhadap Kemampuan Mendeteksi Kecurangan (Fraud) Pada Auditor di BPK 
RI. Jom FEKON Vol. 2 No. 2.

Srikandi, Y. I. (2015). Pengaruh Kompetensi dan Skeptisme Profesional Auditor Terhadap Pendeteksian Kecurangan (Survey Pada Kantor Akuntan Publik di Wilayah Bandung yang Terdaftar di BPK).

Stuart, Iris C. (2012). Auditing and Assurance Services, An Applied Approach. New York: McGraw-Hill, Inc.

Sugiyono, P. D. (2016). Metode Penelitian Kombinasi (Mix Methods). Bandung: Alfabeta.

\section{PROFIL PENULIS}

Presti Rosiana adalah mahasiswa prodi Akuntansi, Indra Mahardika Putra dan Yopie Aprianto Setiawan adalah dosen prodi Akuntansi, Fakultas Bisnis Institut Teknologi dan Bisnis Kalbisc 